\title{
Depolymerization of Birch-Wood Organosolv \\ Lignin Over Solid Catalysts \\ in Supercritical Ethanol
}

\author{
Artemiy B. Ayusheev*a, Oxana P. Taran ${ }^{\mathrm{a}, \mathrm{b}}$, \\ Irina I. Afinogenova ${ }^{\mathrm{a}, \mathrm{b}}$, Tatyana I. Mishchenko ${ }^{\mathrm{a}}$, \\ Michael V. Shashkova,c, Kseniya A. Sashkinaa, ${ }^{a, c}$ \\ Victoria S. Semeikina ${ }^{a, c}$, Ekaterina V. Parkhomchuk ${ }^{a, c}$ \\ Vladimir E. Agabekov ${ }^{\mathrm{d}}$ and Valentin N. Parmona, \\ ${ }^{a}$ Boreskov Institute of Catalysis SB RAS \\ 5 Lavrentieva, Novosibirsk, 630090, Russia \\ ${ }^{b}$ Novosibirsk State Technical University \\ 20 K. Marx, Novosibirsk, 630092, Russia \\ ${ }^{c}$ Novosibirsk State University \\ 2 Pirogova Str., Novosibirsk, 630090, Russia \\ ${ }^{d}$ Institute of Chemistry of New Materials NAS of Belarus \\ 36 F.Skorina Str., Minsk, 220141, Republic of Belarus
}

Received 04.06.2016, received in revised form 21.07.2016, accepted 03.09.2016

Catalytic depolymerization of birch-wood organosolv lignin was studied in supercritical ethanol at $260{ }^{\circ} \mathrm{C}$. Three different acid-basic materials namely sepiolite, zeolite ZSM-5 supported on $\mathrm{Al}_{2} \mathrm{O}_{3}$ and Sibunit graphite-like mesoporous carbon promoted via oxidation were tested as catalysts. Moreover, Ru-containing catalysts based on these supports were studied. Among the catalysts without ruthenium, Sibunit matherial was found to produce highest yield of liquid products due to the highest amount of surface acid sites.

Precipitating Ru significantly increases the activity of all three supports. Using Ru-containing Sibunit catalyst in lignin depolymerization process allows to avoid coke formation, increases the amount of aromatic monomers and the total yield of liquid products up to $76 \%$. The yield obtained in best catalytic experiment is more then twice higher compared to the process without any catalyst.

Keywords: lignocellulosic biomass, birch wood, holocellulose, organosolv lignin, depolymerization, catalysts.

DOI: $10.17516 / 1998-2836-2016-9-3-353-370$.

(C) Siberian Federal University. All rights reserved

* Corresponding author E-mail address: a.ayusheev@gmail.com 


\title{
Деполимеризация органосольвентного лигнина березы \\ в среде сверхкритического этанола \\ в присутствии твердых катализаторов
}

\author{
А.Б. Аюшеев ${ }^{\mathrm{a}}$, О.П. Таран ${ }^{\mathrm{a}, \boldsymbol{0}}$, \\ И.И. Афиногенова ${ }^{\mathrm{a}, \boldsymbol{\sigma}}$, Т.И. Мищенко \\ М.В. Шашков ${ }^{\mathrm{a}, \mathrm{s}}$, К.А. Сашкина ${ }^{\mathrm{a}, \mathrm{s}}$, В.С. Семейкина ${ }^{\mathrm{a}, \mathrm{s}}$, \\ Е.В. Пархомчук ${ }^{\mathrm{a}, \mathrm{s}}$, В.Е. Агабеков ${ }^{\mathrm{r}}$, В.Н. Пармон ${ }^{\mathrm{a}, \mathrm{B}}$ \\ ${ }^{a}$ Институт катализа им. Г.К. Борескова СО РАН \\ Россия, 630090, Новосибирск, пр. Лаврентьева, 5 \\ ${ }^{6}$ Новосибирский государственный технический университет \\ Россия, 630073, Новосибирск, пр. К. Маркса, 20 \\ ${ }^{8}$ Новосибирский государственный университет \\ Россия, 630090, Новосибирск, ул. Пирогова, 2 \\ 'Институт химии новых материалов НАН Беларуси \\ Беларусь, 220141, Минск, ул Ф. Скаринь, 36
}

Проведено исследование процесса каталитической деполимеризации органосольвентного лигнина в среде сверхкритического этанола при $260{ }^{\circ} \mathrm{C}$. В качестве катализаторов были испытаны материалы с различными кислотно-основными свойствами: сепиолит, иеолит ZSM-5 на $\mathrm{Al}_{2} \mathrm{O}_{3}$ и модифицุированный окислением углеродный материал Сибунит, а также Ru-содержащие катализаторы, приготовленные на основе вылеперечисленных материалов. Установлено, что среди катализаторов, не содержащчих рутений, наиболее высокие значения выхода жидких продуктов удалось достичь при использовании углеродного образца, обладающего наибольиим числом кислотных ичентров.

Нанесение Rи на все типь носителей привело к значительному увеличению их каталитической активности. Использование Ru-содержащуего катализатора на основе Сибунита в процессе деполимеризации лигнина позволило избежать прощесса коксообразования, увеличить количество ароматических мономеров и общчий выход жидких продуктов до 76 \%, что более чем в два раза выше по сравнению с экспериментом без катализатора.

Ключевые слова: лигноцеллюлозная биомасса, древесина берёзы, холочеллюлоза, лигнин, органосольвентная варка, деполимеризация, катализаторы.

\section{Введение}

В настоящее время в развитых странах мира интенсифицировались исследования, направленные на расширенное использование и комплексную переработку растительной биомассы как альтернативы ископаемому сырью. Биомасса растительного происхождения является быстро возобновляемым сырьем, которое может служить практически неисчерпаемым источником для получения востребованных химических веществ, биотоплива и материалов различного назначения. Ежегодно в мире образуется более 170 млрд т биомас- 
сы [1]. Лигноцеллюлозное растительное сырье , составляющее 99 \% от всей биомассы, это комплекс биополимеров сложного состава. Основные его компоненты: целлюлоза (40 60 мас. \%), гемицеллюлозы (до 30 мас. \%) и лигнин (15 $\div 30$ мас. \%). Вовлечение лигнина, представляющего собой трехмерный органический полимер сложной структуры, в превращения и получение из него ценных продуктов - наиболее сложный процесс для традиционных технологий переработки лигноцеллюлозной биомассы (целлюлозно-бумажное и гидролизное производство)

Благодаря современному направлению на разработку технологий комплексной переработки биомассы значительно возрос интерес к переработке лигнина, являющегося потенциальным источником ароматических соединений, которые могут использоваться в качестве компонентов топлива или сырья для химической промышленности. Ключевые этапы в переработке лигнина - его эффективное квалифицированное извлечение из биомассы и деполимеризация, позволяющая разрушить сложные полимерные структуры до более простых соединений, легче подвергающихся дальнейшим превращениям [2-4]. Перспективным процессом извлечения лигнина признана так называемая органосольвентная варка, т.е. варка в органических растворителях без использования кислот и, следовательно, без образования серо- и хлорсодержащих высокополимеризованных лигнинов [5-7].

Каталитическая деполимеризация лигнина с использованием сверхкритических флюидов представляется весьма перспективным методом переработки органосольвентных лигнинов [8-11]. Как правило, процесс проводится при температурах $250-400^{\circ} \mathrm{C}$, а в качестве растворителей выступают вода, метанол и этанол. Однако применение этанола позволяет достичь более высоких выходов мономерных ароматических продуктов по сравнению с метанолом [12]. Применение катализаторов в процессе деполимеризации лигнина в сверхкритических условиях дает возможность значительно увеличить выход мономерных ароматических продуктов и снизить или избежать образования побочного продукта реполимеризации - кокса. В литературе имеются данные об активности катализаторов различной кислотно-основной природы, как кислотных [9], так и основных [12-13], в процессах конверсии лигнина в среде сверхкритических растворителей. Например, в работе [9] применение цеолитных катализаторов в процессе термической конверсии лигнина древесины осины в сверхкритическом этаноле помогло увеличить степень конверсии лигнина древесины осины на 20-30 \% по сравнению с некаталитическим процессом. Использование пористых оксидов меди $\left(\mathrm{Cu}_{20} \mathrm{La}_{20} \mathrm{PMO}\right)$ в процессе деполимеризации органосольвентного лигнина в среде сверхкритического метанола при $310{ }^{\circ} \mathrm{C}$ позволило добиться выходов жидких продуктов свыше 50 \% [11]. Huang и соавторы в своих работах $[12,13]$ в присутствии катализатора на основе гексаалюминатов $(\mathrm{CuMgAlO}$ x при $380{ }^{\circ} \mathrm{C}$ достигли высоких выходов алкилированных ароматических мономеров (60-86 \% в зависимости от типа использованного лигнина) без образования существенных количеств кокса. Таким образом, в литературе до сих пор нет единого мнения о том, какими кислотноосновными свойствами должен обладать эффективный в процессе деполимеризации лигнина твердый катализатор.

С другой стороны, катализаторы, содержащие нанодисперсные металлы платиновой группы и никель, являются эффективными катализаторами гидрогенолиза лигнина в присутствии водорода и водородно-донорных агентов $[14,15]$. Принимая во внимание то, что спирты, при- 
меняемые в качестве растворителей в реакциях деполимеризации лигнина, способны выступать в качестве доноров водорода $[12,13]$, можно полагать, что металлические катализаторы на основе носителей с подходящими кислотно-основными свойствами могут стать весьма эффективными катализаторами конверсии органосольвентного лигнина в жидкие продукты в сверхкритических условиях.

Целью настоящей работы стало определение влияния каталитических центров различной природы (кислотные, основные, металлические) на эффективность и выходы продуктов процесса деполимеризации органосольвентного лигнина древесины березы в сверхкритическом этаноле. В качестве твердых катализаторов с различными кислотно-основными свойствами в работе использовались: основный - сепиолит, кислотные - цеолит ZSM-5/ $\mathrm{Al}_{2} \mathrm{O}_{3}$ и окисленный углеродный материал Сибунит, а также вышеперечисленные катализаторы, допированные $\mathrm{Ru}$.

\section{Материалы и методы}

\section{Выделение лигнина}

Образцы лигнина получали из древесины берёзы белой (Betula alba) по методике органосольвентной варки древесины, адаптированной из работ [16, 17]. Воздушно-сухие опилки древесины предварительно обессмоливали диэтиловым эфиром в аппарате Сокслета в течение 4 ч [18]. Варку проводили в автоклаве высокого давления (Neuro 100, AmAr equipments, Индия). 10 г обессмоленных опилок и 100 мл водно-этанольного раствора (EtOH/ $\mathrm{H}_{2} \mathrm{O}=60 / 40$ об. \%) загружали в реактор, который герметизировали, триджы продували аргоном, устанавливали давление аргона 1 МПа, нагревали до $190{ }^{\circ} \mathrm{C}$. Реакцию проводили при постоянном перемешивании 1000 об/мин в течение 90 мин. По завершении процесса реактор охлаждали до комнатной температуры. Полученные продукты выгружали из реактора. Осадок отделяли от жидкости фильтрацией через воронку Бюхнера с использованием фильтра «белая лента», промывали несколько раз смесью $\mathrm{EtOH} / \mathrm{H}_{2} \mathrm{O}=60 / 40$ об. \% до бесцветного раствора. Жидкость после промывки соединяли с раствором, отделенным в результате фильтрации. Раствор и подкисленную до $1,5 \mathrm{pH}$ (с использованием 0,1 н раствора $\mathrm{HCl}$ ) дистиллированную воду охлаждали до температуры $(5 \pm 1){ }^{\circ} \mathrm{C}$ в морозильной камере. Охлажденные растворы смешивали в объемном соотношении 1:2. После отстаивания в течение 16 ч, что приводило к укрупнению частиц осадка, производили фильтрацию через ацетатцеллюлозный фильтр с размером пор 20 мкм. Полученный осадок (лигнин) сушили в термошкафу при температуре $(50 \pm 3){ }^{\circ} \mathrm{C}$ до постоянной массы. Выход лигнина составил 58 \% от общего содержания лигнина в древесине березы.

Выделенный лигнин исследовали методом ИК-спектроскопии на спектрометре FTIR ShimadzuIRAffinity-1 (Япония) в области 400-450 $\mathrm{cm}^{-1}$ (разрешение $4 \mathrm{~cm}^{-1}$, число сканов 25). Образцы для ИК-спектроскопических исследований готовили в виде таблеток с $\mathrm{KBr}$ в мольном соотношении 1:150. Спектры интерпретировали на основе литературных данных [19].

\section{Приготовление катализаторов}

Для проведения процесса деполимеризации готовили и исследовали катализаторы с различными кислотно-основными свойствами. В качестве кислотных катализаторов были приго-

$$
-356-
$$


товлены цеолит на оксиде алюминия $\left(\mathrm{ZSM}-5 / \mathrm{Al}_{2} \mathrm{O}_{3}\right)$ и модифицированный углеродный материал Сибунит (Sib), а также рутениевые катализаторы, нанесенные на эти носители.

Синтез ZSM-5/ $/ \mathrm{Al}_{2} \mathrm{O}_{3}$ осуществляли по следующей методике. Раствор № I: 100 мл тетраэтилортосиликата («Ангара-реактив») и 100 мл этанола (95\%, «Фармацея»). Раствор № II: 100 мл дистиллированной воды, 100 мл гидроксида тетрапропиламмония (ТПАОН 25 мас. \% водный раствор, Acros) и 19 мл $\mathrm{NaOH}$ (3.85 г/л). Гель $\mathrm{Al}(\mathrm{OH})_{3} \cdot \mathrm{X} \mathrm{H}_{2} \mathrm{O}: 50$ г $\mathrm{AlCl}_{3} \cdot 6 \mathrm{H}_{2} \mathrm{O}$ (Acros) pacтворяли в 50 мл $\mathrm{H}_{2} \mathrm{O}$, затем добавляли к раствору 25 мл концентрированного $\mathrm{NH}_{4} \mathrm{OH}$, отделяли осадок, промывали дистиллированной водой. Раствор № III: 11,3 г $\mathrm{Al}(\mathrm{OH})_{3} \cdot \mathrm{H}_{2} \mathrm{O}$ добавляли к 50 мл раствора II, перемешивали в течение 1 ч. Раствор I добавляли в оставшийся раствор II, полученную смесь перемешивали 10 мин, затем прикапывали раствор III с последующим пере $\neg$ мешиванием в течение 10 мин. Образовавшуюся смесь в тефлоновых стаканчиках помещали в автоклав и оставляли при $150{ }^{\circ} \mathrm{C}$ на 24 ч. Продукты синтеза отделяли от маточных растворов с помощью центрифугирования, затем промывали дистиллированной водой до $\mathrm{pH}$ $=7$ за три серии очистки, состоящих из добавления воды, диспергирования в ультразвуковой ванне, центрифугирования и отделения жидкости. Затем продукты синтеза высушивали при $100{ }^{\circ} \mathrm{C}$ в течение 12 ч. Полученные образцы прокаливали при $550{ }^{\circ} \mathrm{C}$ в течение 5 ч, до температуры прокаливания нагревали линейно в течение 3 ч. К 30 г псевдобемита (AlOOH) добавляли раствор 0,45 г полиэтиленгликоля (Sigma-aldrich) в 20 мл дистиллированной воды при тщательном перемешивании, потом - пасту из 3 г полистирольных сфер и 4 мл этанола, затем - 9 г приготовленного ранее цеолита ZSM-5. Пасту перемешивали 30 мин. После чего материал сушили 24 ч при комнатной температуре, затем 12 ч при $100{ }^{\circ} \mathrm{C}$, прокаливали при $900{ }^{\circ} \mathrm{C}$ в течение 4 ч, до температуры прокаливания нагревали линейно в течение 9 ч. Содержание цеолита ZSM-5 в составе приготовленного материала равнялось $36 \%$.

Углеродный носитель Сибунит перед его модификацией по описанной ранее методике [20] многократно промывали горячей дистиллированной водой для удаления возможных примесей металлов. Далее помещали в стеклянный реактор и сушили в токе аргона при $160{ }^{\circ} \mathrm{C}$. Затем углеродный образец измельчали и отсеивали фракцию с размером частиц 56 - 96 мкм. Окисление углеродного образца «Сибунит-4» $\left(15\right.$ г) проводили в течение 4 ч при $450{ }^{\circ} \mathrm{C}$ в токе воздуха, насыщенного парами воды в сатураторе при $90^{\circ} \mathrm{C}$, с предварительным повторным продуванием образца аргоном в течение 30 мин [20].

Рутенийсодержащие катализаторы на основе окисленного Сибунита (3 \% Ru/Sib) и ZSM$5 / \mathrm{Al}_{2} \mathrm{O}_{3}$ (3\% Ru/ZSM-5/ $/ \mathrm{Al}_{2} \mathrm{O}_{3}$ ) готовили по ранее описанной методике [21]. Катализаторы на основе Сибунита и цеолита получали методом пропитки по влагоемкости водным раствором $\mathrm{Ru}(\mathrm{NO})\left(\mathrm{NO}_{3}\right)_{3}(84,8$ г $\mathrm{Ru}$ на 1 л) с последующей сушкой при комнатной температуре в течение 3 ч и при $60^{\circ} \mathrm{C}$ в течение ночи. Восстановление активного компонента проводили в токе водорода (200 мл/мин) при $300{ }^{\circ} \mathrm{C}$ в течение 2 ч, подъем температуры осуществляли со скоростью $1{ }^{\circ} \mathrm{C} /$ мин, после остывания до комнатной температуры в атмосфере водорода катализатор пассивировали газовой смесью $1 \% \mathrm{O}_{2}$ в азоте.

В качестве катализатора, содержащего не только кислотные, но и основные центры, синтезировали и исследовали природный минерал сепиолит (Sep), модифицированный 1 \% фосфора для повышения стойкости в жидкофазных высокотемпературных реакциях [22]. Образцы сепиолита 1 \% Р готовили по методике [22], согласно которой 150 г предварительно измельченно- 
го порошка сепиолита смешивали с водой (подкисленной $\mathrm{H}_{3} \mathrm{PO}_{4}$ ) до пастообразного состояния с требуемым содержанием фосфора (1 \%). В процессе приготовления наблюдали интенсивное выделение газа. В результате был получен модифицированный сепиолит, основными компонентами которого являлись $\mathrm{Mg}_{2}\left(\mathrm{SiO}_{4}\right)_{2}(17,6 \%), \mathrm{MgO}(38,9 \%), \mathrm{Ca}_{3} \mathrm{Mg}_{2}\left(\mathrm{SiO}_{4}\right)_{2}$ (43,5 \%). Образец высушивали на воздухе в течение 1 дня и обрабатывали нагреванием при $800{ }^{\circ} \mathrm{C}$ в течение 4 ч со скоростью нагрева $100{ }^{\circ} \mathrm{C}$ в час.

Рутенийсодержащий катализатор на основе сепиолита (1\% Ru/Sep) готовили по описанной ранее методике [21] с использованием не водного, а этанольного раствора $\mathrm{Ru}(\mathrm{NO})\left(\mathrm{NO}_{3}\right)_{3}$ для предотвращения возможных химических взаимодействий сепиолита с водой.

\section{Исследование катализаторов физико-химическими методами}

Фазовый состав образцов определяли методом рентгенофазового анализа (РФА) на диф-

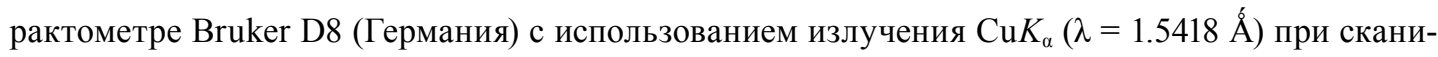
ровании по точкам с интервалом $0,05^{\circ}$ в диапазоне $2 \theta$ от 20 до $80^{\circ}$.

Текстурные характеристики образцов исследовали по изотермам адсорбции $\mathrm{N}_{2}$ при температуре минус $196^{\circ} \mathrm{C}$ на установке ASAP-2400 (Micromeritics, CША). Все образцы предварительно дегазировали в вакууме при температуре $150{ }^{\circ} \mathrm{C}$. Удельную площадь поверхности определяли при помощи классической модели БЕТ.

Электронные микрофотографии высокого разрешения и распределение частиц рутения по размерам для Ru-содержащих катализаторов получали с помощью просвечивающего электронного микроскопа ЈЕМ-2010 (Япония) с ускоряющим напряжением 200 кВ и разрешением $1.4 \AA ̊$. Гистограммы распределения частиц по размерам получали с применением статистической (200-500 частиц) обработки микрофотографий. Значения среднестатистического линейного $\left(<\mathrm{d}_{1}>\right)$ диаметра нанесенных частиц рассчитывали по формуле

$$
<\mathrm{d}_{1}>=\Sigma \mathrm{d}_{\mathrm{i}} / \mathrm{N}
$$

где $\mathrm{d}_{\mathrm{i}}$ - диаметр нанесенной частицы; $\mathrm{N}$ - общее число частиц [23].

\section{Каталитическая деполимеризаџия лигнина}

Эксперименты по деполимеризации лигнина проводили в автоклаве высокого давления модели Neuro 100 (AmAr equipments, Индия) по модифицированной методике [24]. Деполимеризацию осуществляли в сверхкритических условиях с использованием в качестве растворителя этанола (критическая точка этанола $240,7^{\circ} \mathrm{C}$ и $6,4 \mathrm{MПа).} 1,5$ г органосольвентного лигнина древесины березы и 0,75 г катализатора загружали в реактор, добавляли 150 мл этанола, затем реактор герметизировали, трижды продували аргоном, устанавливали нужную температуру. Реакцию проводили в сверхкритических условиях при температуре $260{ }^{\circ} \mathrm{C}$ и постоянном перемешивании 1500 об/мин в течение 6 ч. В начале реакции давление при комнатной температуре было меньше 1 МПа. Во время реакции давление паров реакционной смеси находилось на уровне 6-7 МПа. Давление и температура в ходе процесса контролировали при помощи программного обеспечения Amar Das 3.1.

По завершении процесса реактор охлаждали до комнатной температуры, из него выгружали полученную смесь. После охлаждения проводили отбор газовой фазы и её анализ методом 
газовой хроматографии. Осадок от жидкости отделяли путем фильтрации через воронку Бюхнера с ацетатцеллюлозным фильтром с размером пор 20 мкм. Осадок промывали несколько раз этанолом до тех пор, пока раствор не становился бесцветным. Твердый осадок сушили в сушильном шкафу при температуре $(100 \pm 3){ }^{\circ} \mathrm{C}$ до постоянной массы. Полученную после промывки жидкость соединяли с раствором, отделенным после фильтрации. Из фильтрата отбирали аликвотную часть для исследования состава жидких продуктов. Выход экстракта определяли весовым методом после удаления растворителя. В связи со сложностью удаления твердого осадка со стенок реактора количество кокса, образовавшегося после реакции, определяли по разнице массы загружаемого образца лигнина и суммы жидких и газообразных продуктов.

\section{Аналитические методики}

Содержание лигнина в древесине березы устанавливали сернокислотным методом с использованием $72 \% \mathrm{H}_{2} \mathrm{SO}_{4}[18]$.

Содержание моносахаридов в исходном сырье выявляли методом ВЭЖХ с предварительной дериватизацией образцов 2,4-динитрофенилгидразином, поглощающих свет на длине волны 360 нм, с последующим их разделением и определением на хроматографе «Милихром-А-02» [25].

Анализ газов проводили с помощью газового хроматографа «Кристалл 2000 М» («Хроматек», Россия) с пламенно-ионизационным детектором. Использовалась колонка Хромосорб $102(2 \mathrm{M} \times 2 \mathrm{Mм})$. В качестве газа-носителя применяли аргон (расход 12 мл/мин). Температура детектора $200{ }^{\circ} \mathrm{C}$, испарителя $-150{ }^{\circ} \mathrm{C}$, колонки $-60^{\circ} \mathrm{C}$.

Жидкую фракцию изучали методом ГХ/МС анализа (Agilent 7000 В, США) с использованием колонки VF-5ms30m $\times 0,25 \mathrm{~mm} \times 0,25$ мкм. Условия разделения: программирование температуры осуществляли со скоростью $10^{\circ} \mathrm{C} /$ мин от 120 до $300^{\circ} \mathrm{C}$. Скорость потока газа-носителя (гелий) 1,2 мл/мин. Температура испарителя $300^{\circ} \mathrm{C}$. Ввод пробы 3 мкл, сброс с испарителя 1:10. Для количественной оценки содержания ароматических мономеров использовали внутренний стандарт ионол, который является представителем класса фенолов и не встречается в природе в чистом виде. Идентификацию компонентов проводили по библиотеке масс-спектров NIST'11. Количество олигомеров определяли как разницу между массой всех жидких продуктов и общим количеством ароматических мономеров.

\section{Результаты и обсуждение}

\section{Характеристика исходного сырья}

В качестве исходного сырья в работе использовалась древесина березы белой (Betula alba), активированная в ударно-вихревой мельнице [26]. Средний размер частиц активированных опилок составлял $(22 \pm 13)$ мкм. Содержание экстрактивных веществ, выделенных в результате экстракции диэтиловым эфиром, было 1,5 \%. Влажность биомассы, определенная после извлечения смолистых веществ, равнялась 3 \%. Далее в работе использовали воздушно-сухие опилки, делая поправку на влажность при расчете результатов эксперимента.

Определение содержания лигнина и гемицеллюлоз также проводили для воздушно-сухих обессмоленных опилок (рис. 1). Гидролиз древесины березы и анализ полученных сахаров методом ВЭЖХ позволил определить, что в состав гемицеллюлоз входят галактоза, манноза и 


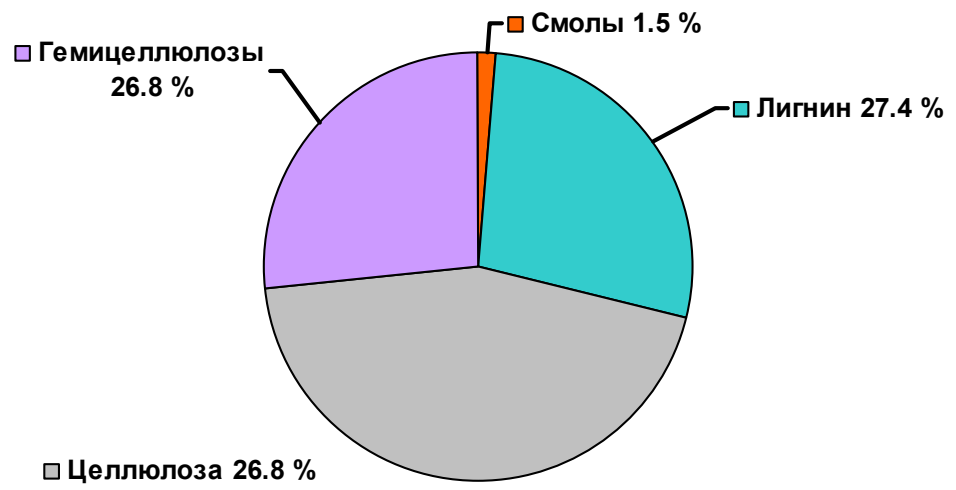

Рис. 1. Компонентный состав древесины березы

ксилоза. Основным компонентом гемицеллюлоз являлась ксилоза (>80 \%), что хорошо согласуется с литературными данными [18]. Суммарное содержание гемицеллюлоз в исследуемых образцах древесины березы составило 26,8 \%. Содержание лигнина, определенное сернокислотным методом, оказалось равным 27,4 \%. Содержание целлюлозы, составившее 44,3 \%, в древесине березы было рассчитано из полученных значений для содержаний гемицеллюлоз, лигнина и экстрактивных веществ. Рассчитанное значение подтверждается результатами анализа растворов на содержание глюкозы после гидролиза древесины концентрированной серной кислотой.

\section{Выделение органосольвентного лигнина из древесины березы}

Варка в органических растворителях считается одним из наиболее перспективных методов делигнификации растительной биомассы. Лигнин, выделенный таким путем, растворим в среде органических спиртов, его легче вовлечь в дальнейшую переработку благодаря низкому молекулярному весу, отсутствию примесей, отравляющих катализаторы, таких как сера и хлор. На рис. 2 представлен ИК-спектр лигнина древесины березы, полученного в результате органосольвентной варки в водно-этанольной смеси. На спектре лигнина можно выделить несколько характерных основных полос пропускания: 1605 - $1593\left(\mathrm{~cm}^{-1}\right)-\mathrm{C}-\mathrm{C}$-валентные колебания ароматического кольца и $\mathrm{C}=\mathrm{O}$ валентные колебания, $1515-1505\left(\mathrm{~cm}^{-1}\right)-\mathrm{C}-\mathrm{C}$-валентные ароматические скелетные колебания (G>S); 1430 - $1422\left(\mathrm{~cm}^{-1}\right)$ - C-C-валентные ароматические скелетные колебания, комбинированные с $\mathrm{C}-\mathrm{H}$-асимметричными плоскостными деформационными колебаниями в метоксильных группах, 1325 - $1330\left(\mathrm{~cm}^{-1}\right)$ - скелетные колебания сирингильного кольца и колебания конденсированного гваяцильного кольца (т.е. гваяцильное кольцо, замещенное в положении 5), 1230 - 1221 ( $\left.\mathrm{cm}^{-1}\right)$ - скелетные колебания сирингильного кольца и С-О-валентные колебания в фенолах, 1128 - $1124\left(\mathrm{~cm}^{-1}\right)$ - ароматические С-Н-плоскостные деформационные колебания (типичны для сирингильных звеньев) и С-О-валентные колебания во вторичных спиртах в совокупности с $\mathrm{C}-\mathrm{O}-\mathrm{C}$-асимметричными валентными колебаниями, 1035 - $1030\left(\mathrm{~cm}^{-1}\right)$ - ароматические $\mathrm{C}-\mathrm{H}$-плоскостные деформационные колебания $(\mathrm{G}>\mathrm{S})$ и $\mathrm{C}-\mathrm{O}$-валентные колебания в первичных спиртах в совокупности с $\mathrm{C}-\mathrm{O}-\mathrm{C}$-симметричными валентными колебаниями (неконъюгированные), 925 - $915\left(\mathrm{~cm}^{-1}\right)$ - C-Н-внеплоскостные де- 


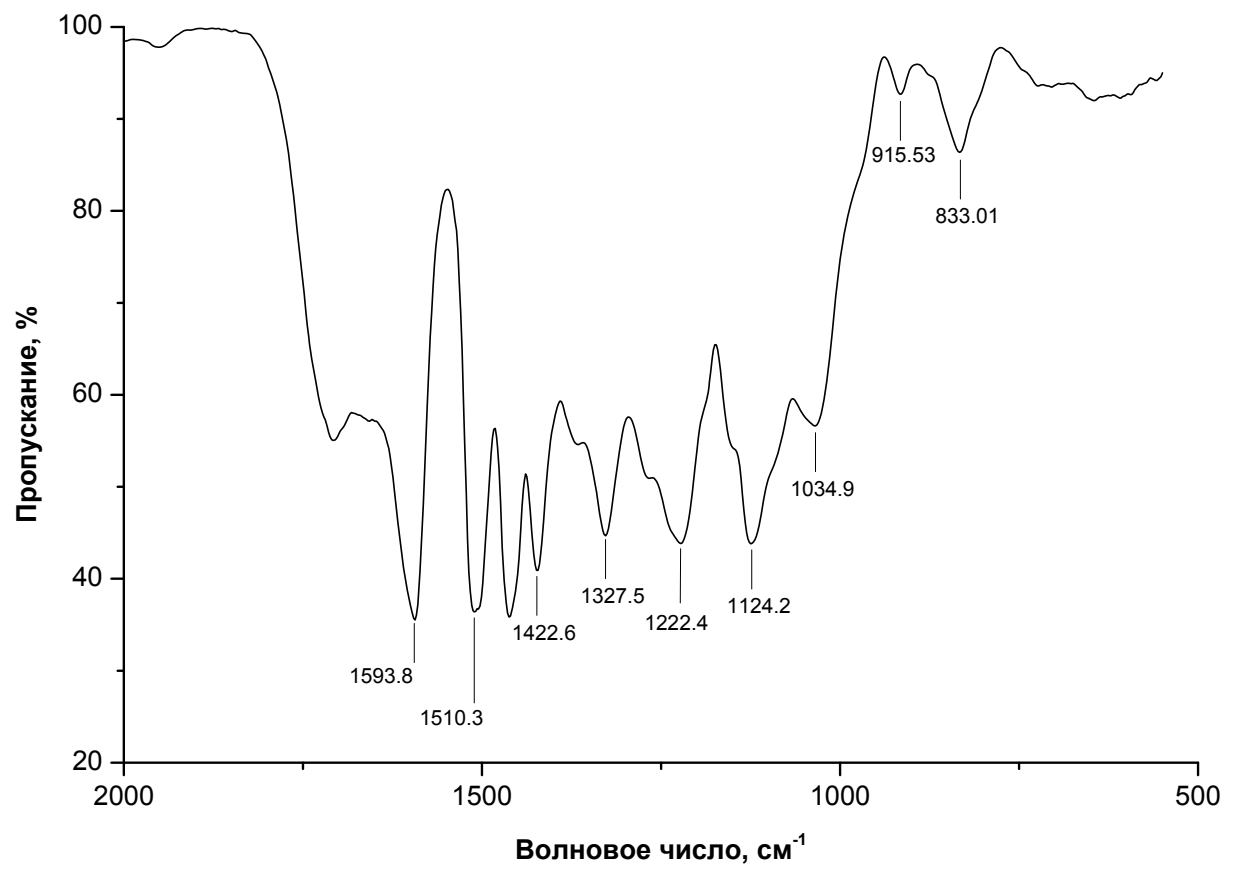

Рис. 2. ИК-спектр органосольвентного лигнина, выделенного из древесины березы

формационные колебания в ароматическом кольце, 835 - $833\left(\right.$ см$\left.^{-1}\right)$ - C-Н-внеплоскостные деформационные колебания в положениях 2 и 6 сирингильного кольца и во всех положениях гидроксиароматических звеньев. Таким образом, ИК-спектр лигнина, полученного органосольвентным методом из древесины березы, соответствует типичному спектру лигнина, представленного в литературе [19], что свидетельствует о том, что был выделен именно лигнин, без значительных примесей полисахаридов.

\section{Исследование катализаторов физико-химическими методами}

Развитая поверхность катализаторов, согласно литературным данным, не важна для жидкофазных процессов, особенно где в качестве субстратов выступают полимерные молекулы (лигнин, целлюлоза и пр.) [2, 27]. Однако кислотно-основные свойства катализаторов играют существенную роль в конверсии лигнина $[9,10]$. В данной работе для процесса деполимеризации лигнина использовали катализаторы, различающиеся кислотно-основными свойствами: сепиолит (Sep), цеолит/ $\mathrm{Al}_{2} \mathrm{O}_{3}\left(\mathrm{ZSM}-5 / \mathrm{Al}_{2} \mathrm{O}_{3}\right)$ и углеродный материал Сибунит ( $\left.\mathrm{Sib}\right)$, окисленный влажным воздухом. Кроме того, эти материалы применяли в качестве носителей для приготовления Ru-содержащих катализаторов. Носители и приготовленные катализаторы исследовали физико-химическими методами (табл. 1). Результаты проведенных исследований показали, что цеолит $/ \mathrm{Al}_{2} \mathrm{O}_{3}$ и Сибунит, окисленный влажным воздухом, имели высокое значение площади удельной поверхности, а сепиолит представлял собой мезо-макропористый материал с низкой поверхностью. Значения удельной площади поверхности $\left(\mathrm{S}_{\mathrm{BET}}\right)$ носителей увеличивались в ряду: сепиолит, цеолит $/ \mathrm{Al}_{2} \mathrm{O}_{3}$, Сибунит и составляли $24,202,348 \mathrm{~m}^{2} / \Gamma$, соответственно. Общий объем пор сепиолита примерно в два раза ниже, чем цеолита $/ \mathrm{Al}_{2} \mathrm{O}_{3}$ и Сибунита. Нанесение 
Таблица 1. Характеристики носителей и рутенийсодержащих катализаторов по данным низкотемпературной адсорбции $\mathrm{N}_{2}$ и просвечивающей электронной микроскопии

\begin{tabular}{|c|c|c|c|c|}
\hline Образец & $\begin{array}{c}\text { Содержание } \\
\text { Ru, \% }\end{array}$ & $\mathrm{S}_{\mathrm{BET}}, \mathrm{M}^{2} / \Gamma$ & $\mathrm{V}_{\text {пор }}, \mathrm{cm}^{3} / \Gamma$ & $<\mathrm{d}>\mathrm{Ru}, \mathrm{HM}$ \\
\hline \multicolumn{5}{|c|}{ Носители } \\
\hline Сепиолит (Sep) & 0 & 24 & 0.23 & - \\
\hline $\mathrm{ZSM}-5 / \mathrm{Al}_{2} \mathrm{O}_{3}$ & 0 & 202 & 0.49 & - \\
\hline Сибунит-4 окисленный (Sib) & 0 & 348 & 0.44 & - \\
\hline \multicolumn{5}{|c|}{ Катализаторы } \\
\hline $1 \% \mathrm{Ru} / \mathrm{Sep}$ & 1 & 29 & 0.27 & 1.3 \\
\hline $3 \% \mathrm{Ru} / \mathrm{ZSM}-5 / \mathrm{Al}_{2} \mathrm{O}_{3}$ & 3 & 145 & 0.33 & 1.5 \\
\hline $3 \% \mathrm{Ru} / \mathrm{Sib}$ & 3 & 306 & 0.49 & 1.5 \\
\hline
\end{tabular}

рутения не привело к значительным изменениям текстурных характеристик катализатора на основе сепиолита. Существенное понижение значений удельной площади поверхности и общего объема пор наблюдалось для образца на основе ZSM-5/Al $\mathrm{O}_{3}$. Это можно объяснить блокировкой узких пор носителя наночастицами активного компонента. Для катализатора Ru/Sib также наблюдалось заметное уменьшение площади удельной поверхности, а значение общего объема пор существенно не изменилось. Следует отметить, что для мезопористого носителя существенное блокирование пор частицами рутения невозможно.

Исследование Ru-содержащих образцов методом просвечивающей электронной микроскопии (ПЭМ) показало, что все образцы содержат на поверхности металлические частицы рутения округлой формы. Средний размер частиц рутения находился в диапазоне от 1,3 до 1,5 нм (табл. 1). Активный компонент (Ru) хорошо распределен по поверхности носителя. Необходимо отметить, что даже для катализатора 1 \% Ru/Sep на носителе (сепиолит) с низкой удельной площадью поверхности удалось добиться равномерного распределения наночастиц рутения по поверхности носителя. Таким образом, выбранный метод приготовления рутенийсодержащих катализаторов позволял приготовить высокодисперсные катализаторы, в том числе и для носителей с низкой удельной площадью поверхности.

Для данной работы особенно важны кислотно-основные характеристики исходных носителей. Кислотность носителей определялась следующими методами: адсорбции аммиака для цеолита $/ \mathrm{Al}_{2} \mathrm{O}_{3}$; адсорбции $\mathrm{CO}$ для сепиолита; кислотно-основного титрования этилатом натрия для углеродного катализатора. Общее количество кислотных центров для образцов цеоли$\mathrm{Ta} / \mathrm{Al}_{2} \mathrm{O}_{3}$, сепиолита и окисленного углеродного материала Сибунита составляло 0,10, 0,36 и 0,36 ммоль/г соответственно. Однако сепиолит кроме льюисовских кислотных центров включал льюисовские основные центры, содержание которых, определенное методом адсорбции дейтерохлороформа, составило 0,1 ммоль/г.

\section{Каталитическая деполимеризация органосольвентного лигнина}

Процесс деполимеризации лигнина проводили при $260{ }^{\circ} \mathrm{C}$ и давлении 6-7,5 МПа. Такие условия позволяли на имеющейся установке достигать состояния сверхкритического флюи- 
да, но являлись более мягкими по сравнению с описанными в литературе $[9,12,13]$. Обычно для уменьшения коксообразования и увеличения выходов мономерных продуктов каталитическую деполимеризацию лигнина проводят при температуре $300{ }^{\circ} \mathrm{C}$ и выше. В результате каталитической конверсии лигнина получались следующие основные группы продуктов: кокс, газы и жидкие углеводороды (табл. 2, 3). Целевым продуктом данной реакции являлись жидкие углеводороды, которые потенциально могут использоваться как сырье для получения ценных химических веществ и высокооктановых топливных добавок. Кокс выступал как крайне нежелательный побочный продукт конверсии лигнина, образующийся в результате его реполимеризации. Образование кокса не только снижает выходы целевых жидких продуктов, но и служит причиной дезактивации катализаторов вследствие зауглероживания и блокировки его активных центров.

Рабочее давление в реакторе изменялось в диапазоне от 6 до 7,5 МПа в зависимости от типа используемого катализатора. Анализ газообразных продуктов методом газовой хроматографии показал, что во всех экспериментах основными продуктами были монооксид углерода и метан (табл. 2). Кроме того, наблюдались небольшие количества двуокиси углерода, этана и пропана. Получаемые $\mathrm{CO}$ и $\mathrm{CH}_{4}$ могут быть использованы для производства синтетического топлива либо в других химических процессах.

Катализаторы с различными кислотно-основными свойствами по-разному влияли на процесс конверсии лигнина. Количество образовавшегося кокса уменьшалось в присутствии чистых носителей в следующем ряду: Sep $>\mathrm{ZSM}-5 / \mathrm{Al}_{2} \mathrm{O}_{3}>\mathrm{Sib}$. Применение катализаторов ZSM-5/ $/ \mathrm{Al}_{2} \mathrm{O}_{3}$ и $\mathrm{Sib}$ способствовало увеличению выхода жидких продуктов на 12 и $20 \%$, соответствен $\neg$ но, по сравнению с некаталитическим процессом. Использование в изучаемом процессе катализатора на основе сепиолита приводило к увеличению выхода кокса и уменьшению выхода жидких продуктов по сравнению с реакцией без катализатора, хотя этот катализатор содержал сравнимое с углеродным материалом Sib количество кислотных центров (0,36 ммоль/г). Однако сепиолит кроме кислотных содержал основные центры, которые, по-видимому, ответственны за процесс коксообразования. Таким образом, использование углеродного катализатора, со-

Таблица 2. Продукты каталитической деполимеризации лигнина

\begin{tabular}{|c|c|c|c|c|c|c|c|c|}
\hline \multirow{3}{*}{ Образец } & \multicolumn{8}{|c|}{ Выход полученных продуктов, \% } \\
\hline & \multirow{2}{*}{ Кокс } & \multicolumn{3}{|c|}{ Жидкие продукты } & \multicolumn{4}{|c|}{ Газообразные продукты } \\
\hline & & Мономеры & Олигомеры & $\sum$ & $\mathrm{CH}_{4}$ & $\mathrm{CO}$ & Другие & $\sum$ \\
\hline Без катализатора & 62.0 & 2.0 & 34.0 & 36.0 & 0.4 & 0.8 & 0.8 & 2.0 \\
\hline \multicolumn{9}{|c|}{ Носители } \\
\hline Sep & 70.0 & 2.6 & 26.4 & 29.0 & - & - & - & $<1$ \\
\hline $\mathrm{ZSM}-5 / \mathrm{Al}_{2} \mathrm{O}_{3}$ & 55.0 & 3.0 & 41.0 & 44.0 & - & - & - & $<1$ \\
\hline Sib & 45.0 & 1.0 & 55.0 & 56.0 & - & - & - & $<1$ \\
\hline \multicolumn{9}{|c|}{ Катализаторы } \\
\hline $1 \% \mathrm{R} / \mathrm{Sep}$ & 23.0 & 6.6 & 59.4 & 66.0 & 7.4 & 7.4 & 0.2 & 15.0 \\
\hline $3 \% \mathrm{Ru} / \mathrm{ZSM}-5 / \mathrm{Al}_{2} \mathrm{O}_{3}$ & - & 7.4 & 70.6 & 78.0 & 11.3 & 10.4 & 0.3 & 22.0 \\
\hline $3 \% \mathrm{Ru} / \mathrm{Sib}$ & - & 10.0 & 66.0 & 76.0 & 11.9 & 11.8 & 0.3 & 24.0 \\
\hline
\end{tabular}


Таблица 3. Содержание мономерных ароматических соединений в составе жидких продуктов каталитической конверсии лигнина

\begin{tabular}{|c|c|c|c|c|c|c|c|c|}
\hline \multirow{2}{*}{ Соединение } & \multirow{2}{*}{$\begin{array}{c}\text { Структурная } \\
\text { формула }\end{array}$} & \multicolumn{7}{|c|}{$\begin{array}{c}\text { Содержание мономерных продуктов } \\
\text { в присутствии различных катализаторов, \%* }\end{array}$} \\
\hline & & $\begin{array}{l}\text { Без } \\
\text { кат. }\end{array}$ & Sep & $\begin{array}{c}\mathrm{ZSM}-5 / \\
\mathrm{Al}_{2} \mathrm{O}_{3}\end{array}$ & Sib & $\begin{array}{l}1 \% \mathrm{Ru} / \\
\mathrm{Sep}\end{array}$ & $\begin{array}{c}3 \% \mathrm{Ru} / \mathrm{ZSM}-5 / \\
\mathrm{Al}_{2} \mathrm{O}_{3}\end{array}$ & $\begin{array}{l}3 \% \mathrm{Ru} / \\
\mathrm{Sib}\end{array}$ \\
\hline 1 & 2 & 3 & 4 & 5 & 6 & 7 & 8 & 9 \\
\hline Сирингол & & 20.6 & 10.5 & 19.9 & 6.0 & 3.0 & 1.8 & - \\
\hline $\begin{array}{l}2,5- \\
\text { диметоксибензиловый } \\
\text { спирт }\end{array}$ & & 4.9 & 3.6 & 3.2 & - & 1.3 & 2.2 & - \\
\hline Изоэвгенол & & 5.8 & 6.7 & 8.0 & 8.3 & 8.6 & 8.0 & 8.2 \\
\hline $\begin{array}{l}\text { 3,4,5-триметокси- } \\
\text { толулол }\end{array}$ & & 6.0 & 8.2 & 3.6 & 2.0 & 8.8 & 10.2 & 4.3 \\
\hline Гваяцилацетон & & 5.4 & 2.2 & & 3.9 & - & - & - \\
\hline Метоксиэвгенол & & 37.6 & 39.6 & 38.9 & 49.8 & 51.7 & 40.5 & 33.2 \\
\hline Метоксиизоэвгенол & & 3.6 & 4.3 & & 4.7 & - & - & 2.5 \\
\hline Ацетосирингон & & 3.6 & 5.5 & 3.0 & 4.2 & - & - & - \\
\hline Дезаспидинол & & 3.4 & 8.4 & 3.6 & 3.8 & - & - & - \\
\hline $\begin{array}{l}\text { 3,4,5-триметокси- } \\
\text { фенилуксусная } \\
\text { кислота }\end{array}$ & & 2.3 & - & - & 1.9 & - & - & - \\
\hline
\end{tabular}


Продолжение табл. 3

\begin{tabular}{|c|c|c|c|c|c|c|c|c|}
\hline 1 & 2 & 3 & 4 & 5 & 6 & 7 & 8 & 9 \\
\hline 4-винилгваякол & $\mathrm{OH}$ & - & - & 1.9 & - & - & - & - \\
\hline $\begin{array}{l}\text { 2,5-диметокси-4- } \\
\text { метилбензальдегид }\end{array}$ & & - & - & 6.5 & - & ב & - & - \\
\hline 4-этилгваякол & & - & - & - & - & 2.1 & 2.3 & 0.5 \\
\hline 4-пропилгваякол & & - & - & - & - & 2.7 & 5.1 & 5.1 \\
\hline 4-пропилсирингол & & - & - & - & - & 18.1 & 26.9 & 45.6 \\
\hline Сирингилальдегид & & - & - & - & 7.5 & - & - & - \\
\hline
\end{tabular}

* \% от суммы площадей всех пиков на хроматограмме; приведены соединения, относительные содержания которых превышают $1 \%$.

держащего максимальное количество кислых центров (0,36 ммоль/г) в отсутствие основных, позволило получить минимальные выходы кокса и максимальные выходы жидких продуктов по сравнению с другими испытанными катализаторами без рутения.

Применение Ru-содержащих катализаторов привело к значительному увеличению выходов жидких (в 1,5-2 раза) и образованию существенных количеств газообразных продуктов, а также уменьшению выхода кокса по сравнению с опытами на соответствующих чистых носителях (табл. 2). Так, количество кокса при использовании 1 \% Ru/Sep снижалось, примерно, в 3 раза по сравнению с экспериментом в присутствии сепиолита. Тогда как на $3 \% \mathrm{Ru} / \mathrm{Sib}$ и $3 \%$ $\mathrm{Ru} / \mathrm{ZSM}-5 / \mathrm{Al}_{2} \mathrm{O}_{3}$ катализаторах, не содержащих основные центры, образования кокса не наблюдалось. В реакциях с рутениевыми катализаторами отмечалось более чем 10 -кратное увеличение выхода газов по сравнению с опытами на носителях. Очевидно, Ru-содержащие катализаторы ускоряли не только деполимеризацию лигнина с образованием жидких продуктов, но и вторичные процессы деструкции образовавшихся продуктов в газы.

Содержания ароматических мономеров в составе жидких продуктов анализировали методом ГХ-МС (табл. 3). Общее количество ароматических мономеров в составе жидких продуктов значительно отличалось в зависимости от типа использованного катализатора (табл. 2, 3). Выход мономерных продуктов каталитической конверсии лигнина увеличивался в ряду 
$\mathrm{Sib}<\mathrm{Sep}, \mathrm{ZSM}-5 / \mathrm{Al}_{2} \mathrm{O}_{3} 1 \% \mathrm{Ru} / \mathrm{Sep}<3 \% \mathrm{Ru} / \mathrm{ZSM}-5 / \mathrm{Al}_{2} \mathrm{O}_{3}<3 \% \mathrm{Ru} / \mathrm{Sib}$. Таким образом, наибольшего выхода ароматических мономеров без образования кокса удалось достичь при использовании $\mathrm{Ru}-$ содержащего катализатора на основе окисленного Сибунита, обладающего наибольшим из исследованных материалов количеством кислотных центров. Хотя для исходных носителей влияние кислотности на выходы мономеров не так однозначно.

Состав ароматических мономеров в жидких продуктах деполимеризации лигнина в присутствии носителей и рутенийсодержащих катализаторов значительно различался (табл. 3). На рис. 3 и 4 представлены хроматограммы жидких продуктов конверсии лигнина в присутствии углеродного носителя Sib и Ru-содержащего катализатора на его основе. Основными мономерными продуктами конверсии лигнина в присутствии катализаторов без рутения оказались метоксиэвгенол и сирингол, содержание которых находилось в интервале 37,6-49,83 и 6,04-20,55 \%, соответственно, в зависимости от типа использованного катализатора. Кроме того, были обнаружены такие соединения как гваяцилацетон, ацетосирингон, дезаспидинол (суммарно до 20 \% от общего содержания мономеров). Эти ароматические соединения не наблюдались в составе жидких продуктов после конверсии лигнина в присутствии Ruсодержащих катализаторов (табл. 3). В случае использования рутенийсодержащих катализаторов основным продуктом помимо метоксиэвгенола (34,04-51,7 \%) был 4-пропилсирингол (18,1-46,74 \%). Следует отметить появление в составе ароматических продуктов 4-этилгваякола и 4-пропилгваякола. Таким образом, в присутствии Ru-содержащих катализаторов про-

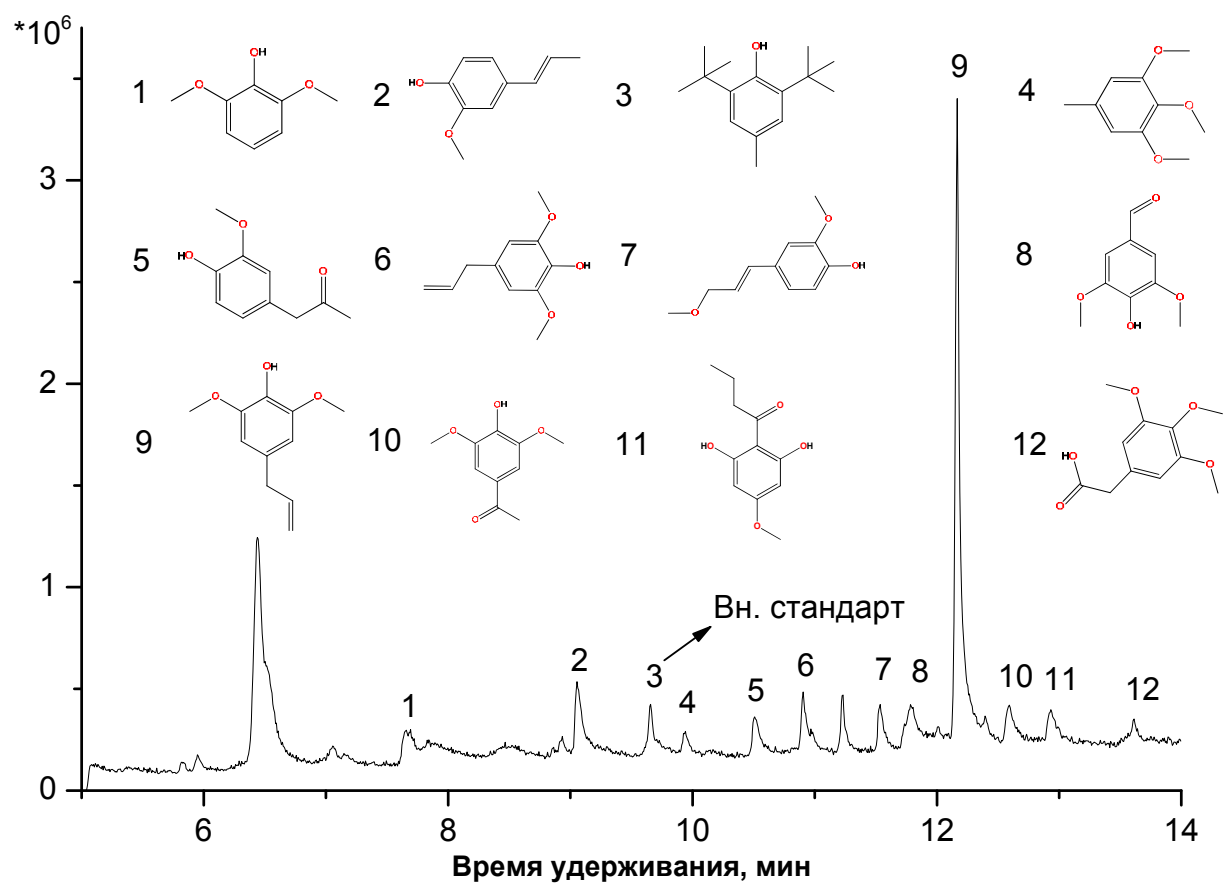

Рис. 3. Хроматограмма жидких продуктов деполимеризации лигнина в присутствии углеродного носителя Сибунит-4 окс (Sib): 1 - сирингол; 2 - изоэвгенол; 3 - внутренний стандарт ионол; 4 - 1,2,3 триметокси5-метилбензол; 5 - гваяцилацетон; 6 - метоксиевгенол (изомер); 7 - метоксиизоэвгенол; 8 - сиреневый альдегид; 9 - метоксиевгенол; 10 - ацетосирингон; 11 - дезаспидинол, 3,4,5-триметоксифенил-уксусная кислота 


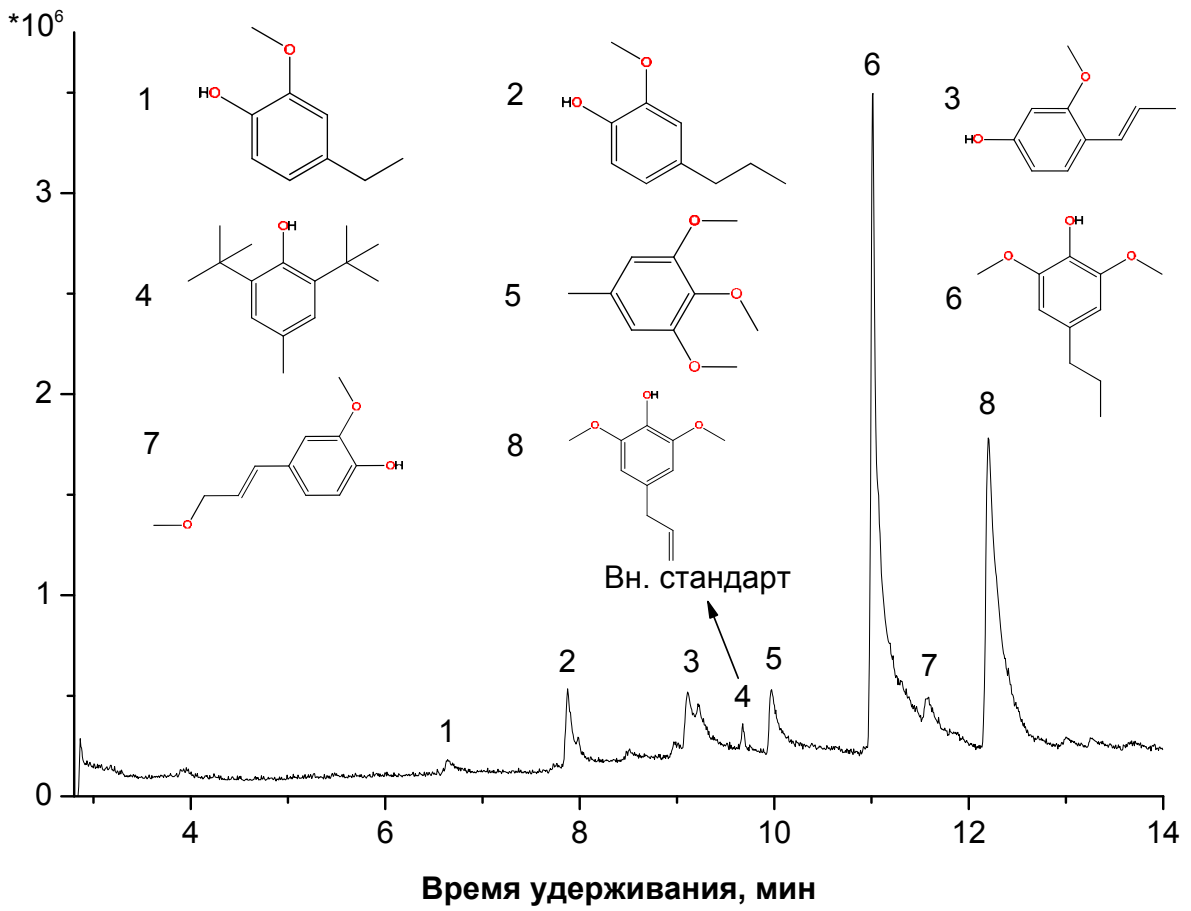

Рис. 4. Хроматограмма жидких продуктов деполимеризации лигнина в присутствии катализатора 3 \% $\mathrm{Ru} / \mathrm{Sib}: 1$ - 4-этилгваякол; 2 - 4-пропилгваякол; 3 - изоэвгенол; 4 - внутренний стандарт ионол; 5 3,4,5-триметокситолуол; 6 - 4-пропилсирингол; 7 - метоксиизоэвгенол; 8- метоксиэвгенол

текает не только процесс гидролиза полимерного лигнина с образованием фенилпропановых мономеров, но и процесс деоксигенации мономеров, в основном их пропановых фрагментов.

Таким образом, наличие кислотных центров в составе катализатора предпочтительно по сравнению с основными, а присутствие рутения приводит к значительному увеличению эффективности конверсии лигнина в сверхкритическом этаноле. Известно, что спирты могут выступать донорами водорода $[12,13,15]$. Катализаторы, содержащие благородные металлы, в том числе $\mathrm{Ru}$, активны в процессах гидрогенолиза органических соединений, т.е. присоединения $\mathrm{H}_{2}$, происходящего с разрывом C-C- и С-Х-связей. По-видимому, именно гидрогенолиз, в котором растворитель выступает в качестве донора водорода, является причиной высокой активности Ru-содержащих катализаторов в деполимеризации лигнина. Для более подробного изучения этого вопроса необходимо дальнейшее исследование.

\section{Заключение}

Проведено исследование процесса каталитической деполимеризации органосольвентного лигнина, выделенного из древесины березы методом варки в водно-этанольной смеси, в среде сверхкритического этанола при $260^{\circ} \mathrm{C}$ в присутствии твердых катализаторов с различными кислотно-основными свойствами (сепиолит, $\mathrm{ZSM}-5 / \mathrm{Al}_{2} \mathrm{O}_{3}$, окисленный углеродный материал Сибунит). Наиболее высокое значение выхода жидких продуктов конверсии лигнина удалось достичь при использовании окисленного Сибунита, обладающего наибольшим среди исследованных катализаторов количеством поверхностных кислотных центров. В присутствии моди-

$$
-367-
$$


фицированного природного материала сепиолита, имеющего в своем составе не только кислотные, но и основные центры, происходит существенное увеличение выхода кокса и уменьшение выхода жидких продуктов по сравнению с некаталитическим процессом. Сделан вывод о том, что именно основные центры на поверхности катализатора ответственны за протекание побочного процесса коксообразования. Основными мономерными продуктами в присутствии всех трех катализаторов без рутения оказались метоксиэвгенол и сирингол и в меньших количествах - гваяцилацетон, ацетосирингон, дезаспидинол.

Нанесение до 3 мас. \% Ru на все типы исследованных носителей привело к значительному увеличению их каталитической активности по отношению к жидким и газообразным продуктам, а также к снижению образования кокса. Использование Ru-содержащего катализатора на окисленном Сибуните позволило увеличить выход мономерных продуктов до 10 \% при суммарном выходе жидких продуктов 76 \%, а также избежать процесса коксообразования. Основными мономерами, полученными на рутенийсодержащих катализаторах кроме метоксиэвгенола, оказались не наблюдавшиеся в отсутствие рутения 4-пропилсирингол, 4-этилгваякол, 4-пропилгваякол. Кроме того, наблюдалась частичная деоксигенация пропановых фрагментов фенилпропановых мономеров, что позволило сделать заключение о протекании процесса гидрогенолиза лигнина на рутении, в котором роль донора водорода выполняет растворитель.

Полученные в результате каталитической деполимеризации лигнина ароматические мономеры в перспективе могут использоваться для производства топливных добавок или как сырье для химической промышленности.

\section{Благодарности}

Работа выполнена при финансовой поддержке комплексной программы СО РАН (№ 03032015-0003).

\section{Список литературы}

1. Барышников В.И., Шарыпов В.И., Береговцова Н.Г. и др Термическое растворение механоактивированной древесины осины в среде до и сверхкритического этанола. Журнал СФУ. 2014. Т.7 . № 3. С. $455-463$.

2. Pandey M.P., Kim C.S. Lignin Depolymerization and Conversion: A Review of Thermochemical Methods. Chem. Eng. Technol. 2011. V. 34. N. 1. P. 29-41.

3. Welker C. M., Balasubramanian V. K., Petti C., Rai K. M., De Bolt S., Mendu V. Engineering plant biomass lignin content and composition for biofuels and bioproducts. Energies. 2015. V. 8 . N. 8. P. 7654-7676.

4. Sluiter J. B., Ruiz R. O., Scarlata C. J., Sluiter A. D.Templeton D. W. Compositional analysis of lignocellulosic feedstocks. 1. Review and description of methods. J. Agric. Food Chem. 2010. V. 58. N. 16. P. $9043-9053$

5. Kim D.E., Pan X. Preliminary study on converting hybrid poplar to high-value chemicals and lignin using organosolv ethanol process. Ind. Eng. Chem. Res. 2010. V. 49. N. 23. P. 12156-12163.

6. Alriols M. G., García A., Llano-ponte R.Labidi J. Combined organosolv and ultrafiltration lignocellulosic biorefinery process. Chem, Eng. J. 2010. V. 157. N. 1. P. 113-120. 
7. Huijgen W. J. J., Reith J. H.Den Uil H. Pretreatment and fractionation of wheat straw by an acetone-based organosolv process. Ind. Eng. Chem. Res. 2010. V. 49. N. 20. P. 10132-10140.

8. Кузнецов Б.Н., Чесноков Н.В., Гарынцева Н.В., Яценкова О.В. Интегрированная каталитическая переработка древесины осины в жидкие и твердые биотоплива. Журнал СФУ. 2013. Т. 3. N. 6. C. $286-298$.

9. Шарыпов В.И., Береговцева Н.Г., Барышников С.В., Кузнецов Б.Н., Восьмериков А.В., Таран О.П., Агабеков В.Е. Термическая конверсия лигнина древесины осины в этаноле в присутствии цеолитных катализаторов. Журнал СФУ. 2013. Т. 3. ․ 6. С.241-250.

10. Güvenatam B., Heeres E.H.J., Pidko E.A., Hensen E.J.M. Lewis-acid catalyzed depolymerization of Protobind lignin in supercritical water and ethanol. Catal. Today. 2016. V. 259. P. 460-466.

11. Warner G., Hansen T.S., Riisager A., Beach E.S., Barta K., Anastas P.T. Depolymerization of organosolv lignin using doped porous metal oxides in supercritical methanol. Bioresour. Technol. 2014. V. 161. P. 78-83.

12. Huang X., Korányi T.I., Boot M. D.Hensen E.J.M. Catalytic depolymerization of lignin in supercritical ethanol. ChemSusChem. 2014. V. 7. N.8. P. 2276-2288.

13. Huang X., Korányi T.I., Boot M.D., Hensen E.J.M. Ethanol as capping agent and formaldehyde scavenger for efficient depolymerization of lignin to aromatics. Green Chem. 2015. V. 17. N.11. P. 49414950.

4. Klein I., Saha B., Abu-Omar M.M. Lignin depolymerization over Ni/C catalyst in methanol, a continuation: Effect of substrate and catalyst loading. Catal. Sci. Technol. 2015. V. 5. N.6. P. 32423245.

5. Kloekhorst A., Shen Y., Yie Y., Fang M. , Heeres H.J. Catalytic hydrodeoxygenation and hydrocracking of Alcell ${ }^{\circledR}$ lignin in alcohol/formic acid mixtures using a $\mathrm{Ru} / \mathrm{C}$ catalyst. Biomass Bioenergy. 2015. V. 80. P. 147-161.

6. Dos Santos P. S. B., De Cademartori P. H. G., Prado R., Gatto D. A., Labidi J. Compositionand structure of organosolv lignins from four eucalypt species. Wood Sci Technol. 2014. V. 48. N. 4. P. 873-885.

7. Wildschut J., Smit A.T., Reith J.H., Huijgen W.J.J. Ethanol-based organosolv fractionation of wheat straw for the production of lignin and enzymatically digestible cellulose Bioresour. Technol. 2013. V. 135. P. 58-66.

8. Оболенская А. В., Ельницкая 3. П.Леонович А. А. Лабороторные работы по химии древесины и целлюлозы. Москва: Экология, 1991. 366 р.

19. Базарнова Н.Г., Карпова Е.В., Катраков И.Б. Методы исследования древесины и ее производных. Барнаул: Изд-во Алт. гос. ун-та, 2002. 160 с.

20. Taran O.P., Descorme C., Polyanskaya E.M., Ayusheev A.B., Besson M., Parmon V.N. Sibunit Based Catalytic Materials for the Deep Oxidation of Organic Ecotoxicants in Aqueous Solutions. III: Wet Air Oxidation of Phenol over Oxidized Carbon and Ru/C Catalysts. Catal. Ind. 2013. V. 5. N 2. P. $164-174$.

21. Таран О.П., Полянская Е.М., Деком К., Огородникова О.Л., Бессон M. Ru/C-катализаторы для глубокого жидкофазного окисления фенола кислородом воздуха в водных растворах. Журнал СФУ. Химия. 2010. Т. 3. № 3. С. 245-252.

$$
-369-
$$


22. Semeykina V., Parkhomchuk E., Polukhin A., Parunin P., Lysikov A., Ayupov A., Cherepanova S., Kaichev V., Glazneva T. CoMoNi Catalyst Texture and Surface Properties in Heavy Oil Processing. Part II: Macroporous Sepiolite-Like Mineral. Ind. Eng. Chem. Res. DOI: 10.1021/acs.iecr.6b01208.

23. Андерсон, Дж. Структура металлических катализаторов. М.: Мир, 1978. С. 482.

24. Ma X., Cui K., Hao W., Ma R., Tian Y., Li Y. Alumina supported molybdenum catalyst for lignin valorization: Effect of reduction temperature. Bioresour. Technol. 2015. V. 192. P. 17-22.

25. Федорова Г.А., Кожанова Л.А. Применение микроколоночной высокоэффективной жидкостной хроматографии в медицине. Часть 2. Вестник восстановительной медицины. 2008. C. 200 .

26. Пестунов А. В., Кузьмин А.О., Яценко Д. А., Правдина М.Х., Таран О.П. Механическая активация чистой и содержащейся в древесных опилках целлюлозы в мельницах различного типа. Журнал Сибирского Федерального университета. Химия. 2015. Т. 8. № 3. С. 386-400.

27. Zakzeski J., Bruijnincx P.C.A., Jongerius A.L., Weckhuysen B.M. The catalytic valorization of lignin for the production of renewable chemicals. Chem. Rev. 2010. V. 110. N. 6. P. 3552-3599. 